\title{
Stimulation of glycosaminoglycan production and lysosomal activity of human synovial cells in culture by low environmental $\mathrm{pH}$
}

\author{
B. J. CLARRIS, J. R. E. FRASER, K. D. MUIRDEN, L. P. MALCOLM, \\ M. W. A. HOLMES, AND K. ROGERS
}

From the University of Melbourne, Department of Medicine, Royal Melbourne Hospital, Victoria 3050, Australia

SUMMARY Glycosaminoglycan production, acid hydrolase activity, proliferation, and morphology were examined in human synovial cells subjected to low environmental $\mathrm{pH}$. The amount and the molecular size of newly synthesised glycosaminoglycan (GAG) were increased without significant change in the rate of cell proliferation. Lowered $\mathrm{pH}$ produced an increase in the size of cytoplasmic organelles. Some of these possessed ultrastructural features of lysosomes, but others were clearly nonlysosomal and were of uncertain identity. Intracellular activity of the lysosomal acid hydrolase $\mathrm{N}$-acetyl- $\mathrm{B}$-glucosaminidase (NAG) was not altered by low $\mathrm{pH}$, but a marked increase occurred in extracellular NAG activity, indicating enhanced release.

Low $\mathrm{pH}$ values have been reported in synovial fluids from inflamed joints of patients with RA..$^{1-3}$ In the most extreme cases this could enhance the activity of free lysosomal enzymes in synovial fluid, particularly for example cathespin $\mathrm{B}$, which is active in the $\mathrm{pH}$ range of $6-7 .^{4} \mathrm{~A}$ further possibility is that increased hydrogen ion concentrations in rheumatoid joints might induce functional changes in synovial intimal cells, which could account for a number of the pathological features of RA, including synovial proliferation, increased activity of lysosomal acid hydrolases in synovial tissue ${ }^{5-6}$ and fluid, ${ }^{7-10}$ and reduced hyaluronic acid viscosity. ${ }^{11}$ To examine this hypothesis glycosaminoglycan production, lysosomal activity, and proliferation of human synovial intimal cells were studied in culture conditions designed to simulate the $\mathrm{pH}$ changes which can occur in rheumatoid joints.

\section{Materials and methods}

Synovial cells. Primary cultures were prepared by trypsinisation of synovial tissue within intact joints of nonarthritic cadaver donors, as described previously. ${ }^{12}$ Cell lines derived from confluent primary cultures were used in early passages while their behaviour was still typical of euploid cells. ${ }^{13}$

Accepted for publication 10 May 1983.

Correspondence to Dr B. J. Clarris.
Culture media and $\mathrm{pH}$ control. Eagle's basal medium (EBM) was used throughout, supplemented with fetal bovine (FS) or human (HS) serum or both. Sera were heated $56^{\circ} \mathrm{C}$ for $30 \mathrm{~min}$ before use. Media were buffered by dilution of $1 \mathrm{M}$ stock solutions of sterile $\mathrm{NaH}_{2} \mathrm{PO}_{4}, \mathrm{NaHCO}_{3}$, and the organic buffers Pipes (piperazine-N,N'-bis(2-ethanesulphonic acid)), Bes (N,N-bis (2-hydroxymethyl)-2-aminoethanesulphonic acid), Hepes (N-2-hydroxyethylpiperazine- $\mathrm{N}^{\prime}$-ethanesulphonic acid), Tes $((\mathrm{N}$-tris hydroxymethyl)methyl-2-aminoethanesulphonic acid), and Epps (N-2-hydroxyethyl-piperazine propanesulphonic acid) in phosphate-free EBM as described by Ceccarini. ${ }^{14}$ The $\mathrm{pH}$ of complete media was adjusted with $1 \mathrm{M} \mathrm{NaOH}$ at $22^{\circ} \mathrm{C}$, using a Radiometer (Copenhagen) $26 \mathrm{pH}$ meter. $\mathrm{pH}$ values at $37^{\circ} \mathrm{C}$ were less than $0.1 \mathrm{pH}$ units higher than at $22^{\circ} \mathrm{C}$. Final concentrations of the individual organic buffers ranged from 5 to $20 \mathrm{mM}$. None of the buffers inhibited the growth of synovial cells at these concentrations. At the termination of experiments supernatant media were sealed in plastic tubes and the final $\mathrm{pH}$ was measured at $22^{\circ} \mathrm{C}$.

EBM and salt solutions (Hanks's balanced salt solutions-HBSS; Dulbecco phosphate buffered sodium chloride-PBS) were obtained from Commonwealth Serum Laboratories, and FS and trypsin from Flow Laboratories Australasia. Lipid-free bovine serum albumin (BSA) was supplied by the 
Sigma Chemical Co. and the organic buffers by Grand Island Biological Co.

Morphology and ultrastructure. Living cultures were examined with phase contrast illumination under an Olympus PMB6 tissue culture microscope. Cultures were prepared for transmissiom electron microscopy (EM) by fixation in situ with $2 \%$ glutaraldehyde in $0.2 \mathrm{M}$ cacodylate buffer, $\mathrm{pH} 7 \cdot 4$, for $10 \mathrm{~min}$ at room temperature, after rinsing with PBS. The cells were detached with a soft scraper, centrifuged into pellets, washed in cacodylate buffer with $7 \cdot 5 \%$ sucrose, and stained with $2 \%$ osmium tetroxide for $30 \mathrm{~min}$ at room temperature. The pellets were dehydrated stepwise in ethanol, embedded in Epon, sectioned, and stained with lead citrate.

Measurement of cell proliferation. Replicate cultures were prepared in polystyrene culture flasks $(25$ $\mathrm{cm}^{2}$ culture surface area) after dispersal of stock cultures with $0.25 \%$ trypsin in $\mathrm{Ca}^{++} / \mathrm{Mg}^{++}$-free PBS. Each flask received $4 \mathrm{ml} \mathrm{EBM}+10 \%$ FS containing approximately $3 \times 10^{5}$ cells. The vessels were sealed and the cells allowed to attach and spread at $37^{\circ} \mathrm{C}$ for 18-24 h. Cultures were allocated to treatments by random numbers. Before test media were added one group of cultures was selected for counting to obtain initial cell numbers. The culture vessels were sealed without adjustment of $\mathrm{CO}_{2}$ in the atmosphere. Initial and final cell numbers were determined with a Coulter counter after complete dispersal with $0.5 \%$ trypsin in $\mathrm{Ca}^{++} / \mathrm{Mg}^{++}$-free PBS.

Assay of NAG. Extracellular activity was measured in $0.5 \mathrm{ml}$ aliquots of the culture supernatants. After the final count $10 \mathrm{ml}$ of the trypsin-cell suspension was centrifuged and the cells disrupted by freezing and thawing 3 times. The broken cells were mixed with $0 \cdot 01 \mathrm{M}$ tris- $\mathrm{HCl}, \mathrm{pH} 7 \cdot 0$, containing $0 \cdot 25$ $M$ sucrose. Intracellular NAG activity was measured in $0.5 \mathrm{ml}$ of the cellular extracts after clarification by centrifugation. NAG was assayed colourimetrically as described previously. ${ }^{15}$

Measurement of glycosaminoglycan (GAG) synthesis. Synovial cultures established in plastic flasks as described above were incubated for $48 \mathrm{~h}$ with $\left[{ }^{3} \mathrm{H}\right]-$ sodium acetate (specific activity $3.8 \mathrm{Ci}$ per mmol; Radiochemical Centre, Amersham) at a final concentration of $20 \mu \mathrm{Ci}$ per $\mathrm{ml}(0.74 \mathrm{mBq}$ per ml). The supernatants were aspirated and $0.25 \mathrm{ml}$ aliquots incubated with 112 units of pronase for $60 \mathrm{~min}$ at $37^{\circ} \mathrm{C}$. After brief centrifugation $20 \mu$ l samples were applied to Whatman $3 \mathrm{M}$ chromatography paper and treated with $0.1 \%$ cetylpyridinium chloride as described by Castor et al. ${ }^{16}$ After washing with $0 \cdot 1 \mathrm{M}$ $\mathrm{NaOH}\left[{ }^{3} \mathrm{H}\right]$-labelled $\mathrm{GAG}$ was measured by liquid scintillation.

Molecular weight analysis of GAG. Culture media containing $\left[{ }^{3} \mathrm{H}\right]$-labelled GAG were centrifuged for
$20 \mathrm{~min}$ at $37000 \mathrm{~g}$ on a Sorvall RC2-B centrifuge. The supernatants were ultracentrifuged at $170000 \mathrm{~g}$ average for $20 \mathrm{~h}$ at $4^{\circ} \mathrm{C}$ on caesium chloride gradients (initial density $1.51 \mathrm{~g} \mathrm{per} \mathrm{ml}$ ). The bottom one-third of the gradient was dialysed exhaustively against

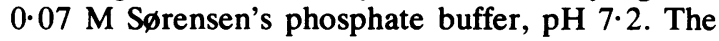
molecular weight distribution of the labelled GAG was analysed by chromatography in Sephacryl S-1000 (Pharmacia Fine Chemicals), with a column $70 \mathrm{~cm}$ in length and $1.6 \mathrm{~cm}$ diameter. The column was eluted with Sørensen's buffer, $\mathrm{pH} 7 \cdot 2$, at a flow rate of $16.7 \mathrm{ml}$ per $\mathrm{h}$ and radioactivity in $2 \mathrm{ml}$ fractions determined by liquid scintillation counting. The elution profile was compared with molecular weight calibration curve provided by courtesy of $\mathrm{Dr} \mathrm{K}$. Granath (Pharmacia AB, Uppsala).

Lactic acid dehydrogenase. This was measured in culture supernatants by the Department of Biochemistry at Royal Melbourne Hospital.

\section{Results}

Stability of $p H$. Despite the organic buffers a drift of up to $0.3 \mathrm{pH}$ units was shown by the difference between initial and final readings (Fig. 1). Single $\mathrm{pH}$ values shown on subsequent figures therefore represent the final reading only.

Effect of $\mathrm{pH}$ on cell proliferation. Multiplication of

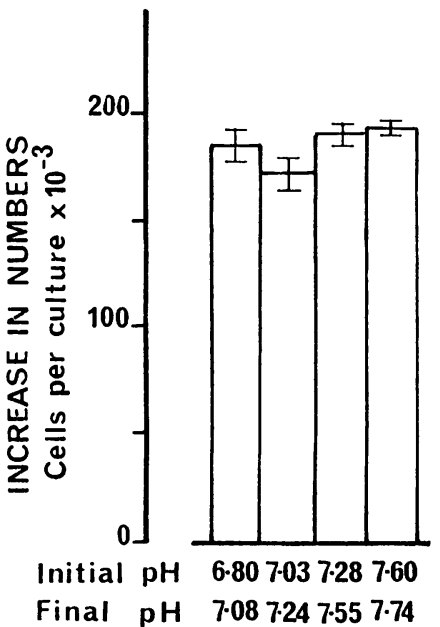

(a)

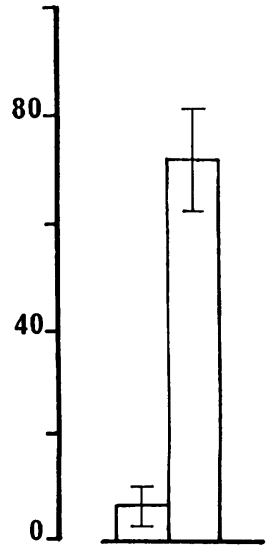

6.727 .59

6.767 .68 (b)

Fig. 1 Effect of environmental $\mathrm{pH}$ on proliferation of synovial cells: (a) and (b) are results from separate experiments. The cells were cultured for $48 \mathrm{~h}$ in $E B M+$ $10 \%$ HS. Vertical bars are mean increases in cell numbers from 4 replicate cultures $( \pm S E M)$. Initial counts were $2.73 \times 10^{5}$ and $2.94 \times 10^{5}$ cells per culture for (a) and (b) respectively. 
synovial cell-lines was previously found to be serum-dependent and proportional to serum concentration. ${ }^{17}$ In the present study serum concentration was standardised at $10 \%(\mathrm{v} / \mathrm{v})$. Human serum was used in preference to FS since the latter contributes a high background in the NAG assay. As shown by Fig. 1(a), a variation in $\mathrm{pH}$ from $7 \cdot 74$ to $7 \cdot 08$ produced no significant alteration in growth rate in $48 \mathrm{~h}$. Longer exposures at $\mathrm{pH}$ values of approximately $7 \cdot 0$ usually resulted in slow loss of cells from the culture surface and littering of the medium with debris and floating cells. Further reduction in $\mathrm{pH}$ below $7 \cdot 0$ produced suppression of growth, but as shown by Fig. 1(b) some net increase in cell numbers still occurred in 2-day experiments at $\mathrm{pH}$ values as low as $6 \cdot 8$. Without serum, proliferation of synovial cells ceases, but cultures can be maintained for at least $48 \mathrm{~h}$ without appreciable loss of cells by replacing serum with BSA at a concentration of $4 \mathrm{mg}$ per $\mathrm{ml}$. As shown by Table 1 , variation of $\mathrm{pH}$ from $7 \cdot 8$ to 6.6 in this medium produced no appreciable change in cell numbers over $48 \mathrm{~h}$.

$G A G$ synthesis. Decrease in $\mathrm{pH}$ produced a highly significant and reproducible increase in GAG synthesis (Fig. 2). The GAG produced at low pH was of exceptionally high molecular weight, with a narrow distribution of polymer sizes (Fig 3 ).

Morphology and ultrastructure. Macrophage-like cells present in the primary phase of isolation are strongly adherent to culture surfaces and do not readily detach with trypsin. Hence after $2-3$ passages synovial cell lines consist entirely of elongated fibroblast-like cells. These normally contain many small and widely distributed cytoplasmic organelles which can be seen by phase contrast microscopy (Fig. 4A). Culture at low $\mathrm{pH}$ appeared to produce an increase in the size of the cytoplasmic organelles and clustering of these bodies round the nucleus (Fig. 4B), but a marked change was not evident in their number. In living cells there was no evidence of enlarged vacuoles, unusual nuclear features, or pro-

Table 1 Effect of variation of $\mathrm{pH}$ on the numbers of synovial cells persisting in serum-free medium* for $48 \mathrm{~h}$

\begin{tabular}{llll}
\hline $\begin{array}{l}\text { Initial cell numbers } \\
\left(\begin{array}{l}\text { mean } \pm S E M) \times 10^{-3} \\
(n=4)\end{array}\right.\end{array}$ & $\begin{array}{l}\text { Initial } \\
p H\end{array}$ & $\begin{array}{l}\text { Final cell numbers } \\
(\text { mean } \pm S E M) \\
\times 10^{-3}\end{array}$ & $\begin{array}{l}\text { Final } \\
p H\end{array}$ \\
\hline $283.9 \pm 3.6$ & 6.50 & $292.9 \pm 4.6$ & 6.61 \\
& 6.95 & $265.9 \pm 11.6$ & 7.19 \\
& 7.37 & $251.5 \pm 16.3$ & 7.62 \\
& 7.55 & $285.2 \pm 1.6$ & $7 \cdot 71$ \\
& 7.74 & $288.5 \pm 4.4$ & 7.82 \\
\hline
\end{tabular}

* Serum was replaced by BSA at $4 \mathrm{mg} / \mathrm{ml}$.

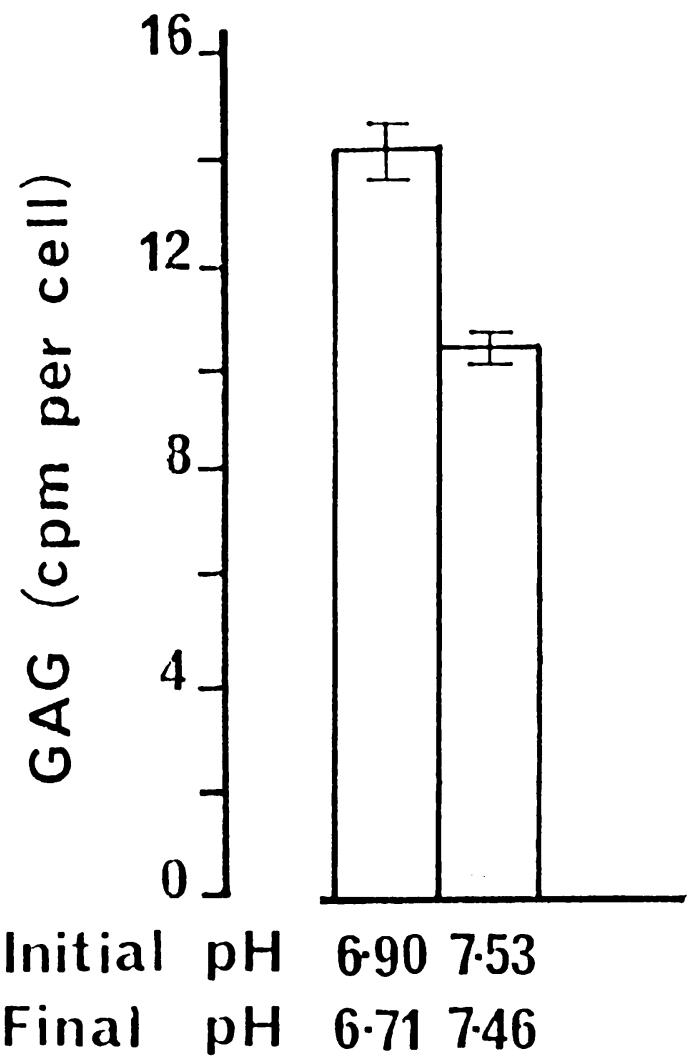

Fig. 2 Effect of decreasing pH on $G A G$ production by synovial cells. The composition of the medium and duration of the experiment were as for Fig. 1. $\left[{ }^{3} \mathrm{H}\right]$-sodium acetate was included in the medium at a final concentration of $20 \mu \mathrm{Ci}$ per $\mathrm{ml}$. The assay was as described in 'Materials and methods.' Vertical bars represent means of determinations from 3 replicate cultures $( \pm S E M)$. The difference is statistically significant (Students t test, $p<0.002$ ).

nounced changes of cell shape in response to low $\mathrm{pH}$. Typical electron microscope fields showed highly elongated cells in control cultures (Fig. 5A), whereas in cultures exposed to low $\mathrm{pH}$ many less elongated, more macrophage-like cells occurred, often with well developed marginal filipodia (Fig 5B). Lysosomes were sparse in the controls, and in many fields none could be seen, as in Fig. 5A. In contrast, the cells exposed to low $\mathrm{pH}$ contained many lysosomal bodies tending to occur in clusters. Hence the large bodies seen by phase contrast microscopy of living cells might represent lysosomal aggregates rather than grossly swollen individual lysosomes, though the mean diameter of single lysosomes was greater than 


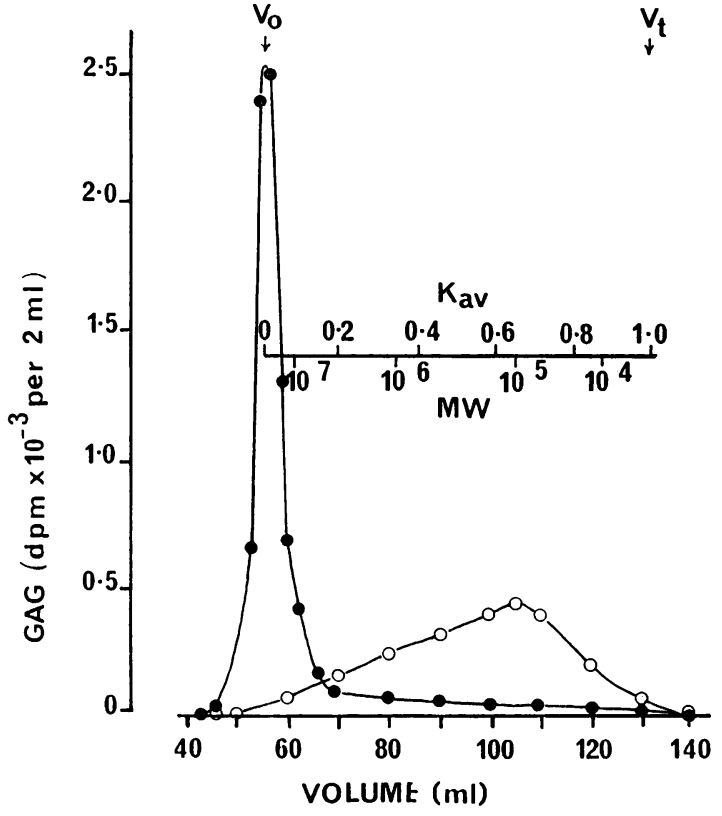

Fig. 3 Effect of pH on molecular weight of $G A G$ produced by synovial cells. The cells were cultured for $48 \mathrm{~h}$ in medium containing $\left[{ }^{3} \mathrm{H}\right]$-sodium acetate as for Fig. 2 at $\mathrm{pH} 7.46$ (O) or 6.71 (О). The supernatants were chromatographed in Sephacryl S-1000 and analysed as described in 'Materials and methods'.

those occurring in control cells. The phenomenon of lysosomal clustering could also explain the apparantly unchanged numbers of organelles noted in the living cells. The synovial cells exposed to low $\mathrm{pH}$ also contained a number of amorphous, clearly nonlysosomal bodies, with approximately the same size range as the lysosomes, which remain unidentified (see example marked $U$ in Fig. 5B).

$N A G$ activity. Decrease in $\mathrm{pH}$ produced no significant alteration in intracellular activity of NAG in synovial cells (Fig. 6).

However, NAG levels increased in the supernatant media. NAG activity levels remained unchanged when the media were subsequently dialysed to $\mathrm{pH}$ $7 \cdot 0$ (Fig. 7), indicating that the increase was due to enhanced release from the cells rather than to any effect on buffering in the enzyme assay. Similar responses occurred in nonproliferating cultures produced by substituting BSA ( $4 \mathrm{mg}$ per $\mathrm{ml}$ ) for serum (Table 2).

$L D H$. None of the treatments caused appreciable release of $\mathrm{LDH}$ from the cells.

\section{Discussion}

Evidence from studies in $\mathrm{RA}^{1-3}$ suggests that tissues

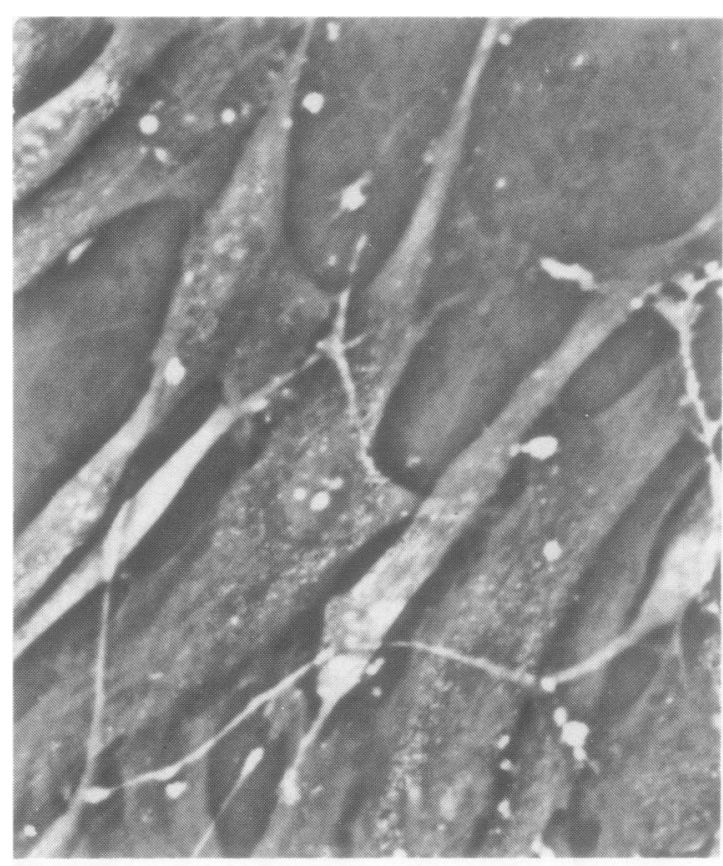

Fig. 4A

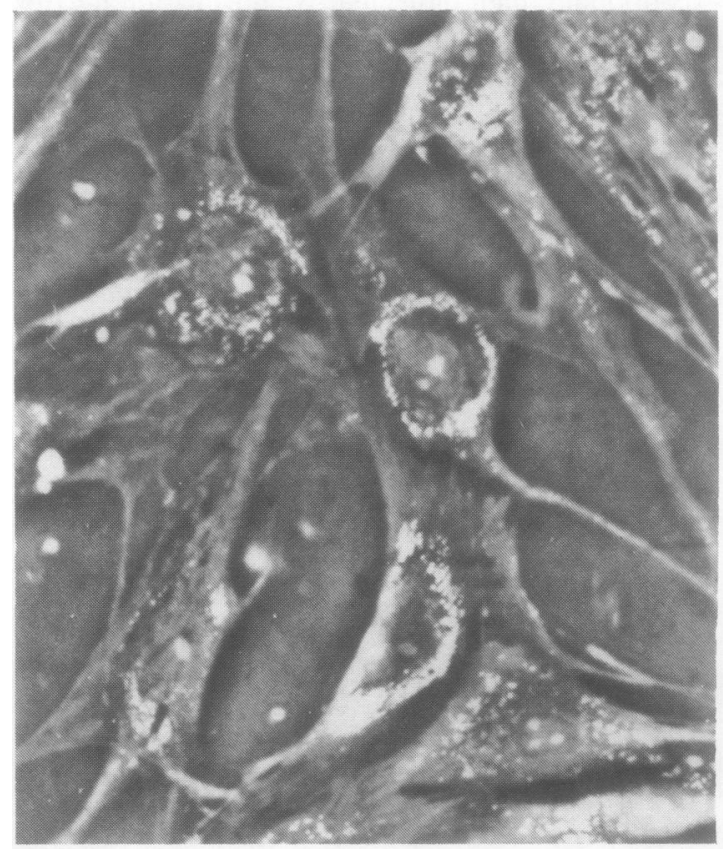

Fig. 4B

Fig. 4 Morphological effects of decreasing $\mathrm{pH}$ on synovial cells. The cultures were photographed after $48 \mathrm{~h}$ in medium at (A) $p H 7 \cdot 50$, (B) $p H 7 \cdot 08$. Note the enlarged cytoplasmic organelles in (B). Negative phase contrast. $(\times 444)$. 


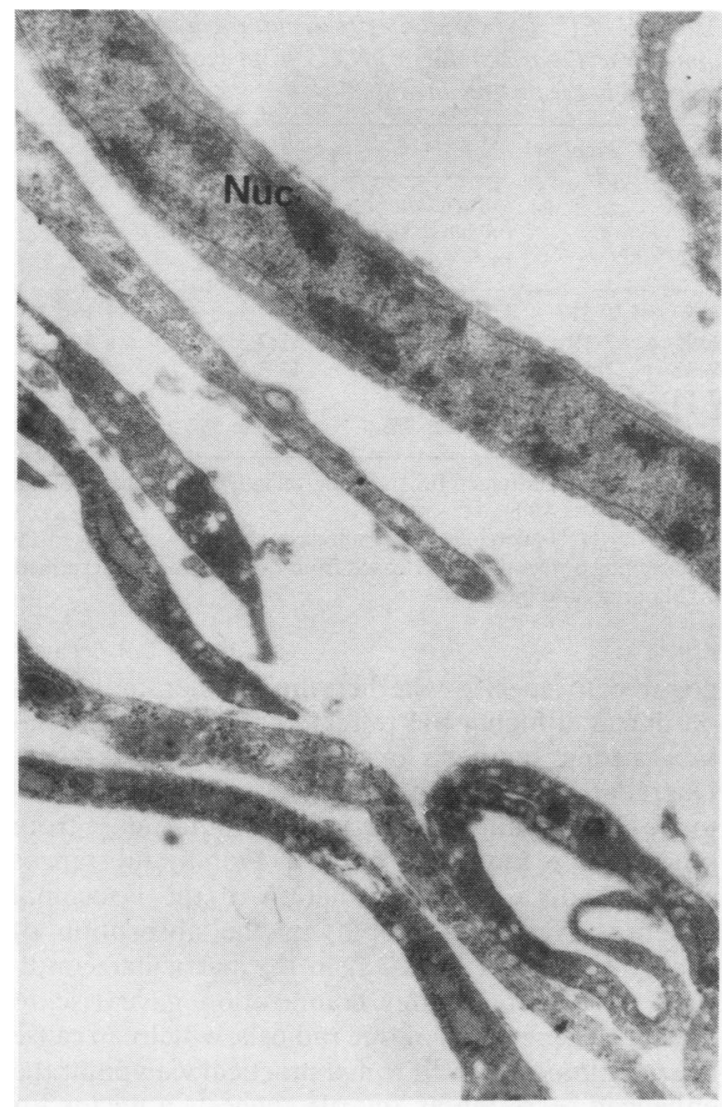

Fig. 5A

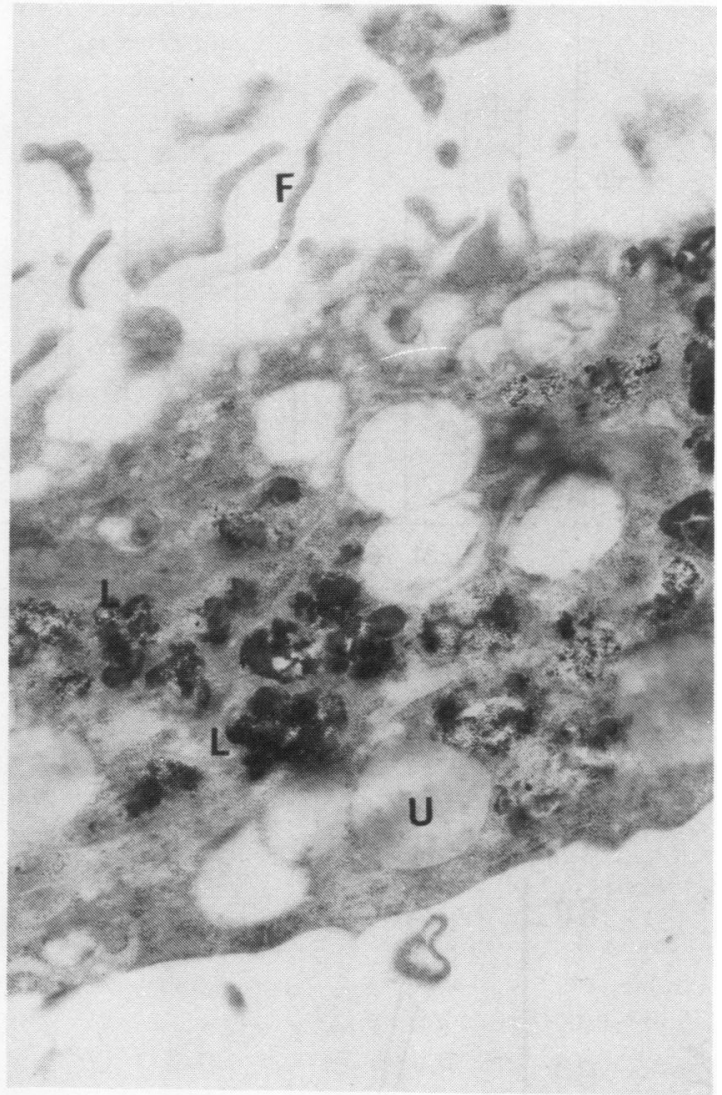

Fig. 5B

Fig. 5 Ultrastructure of synovial cells cultured for 48 h in medium of $\mathrm{HH}$ (A) 7.50 (controls) and (B) 7.08 (low pH). Control cells are elongated, with sparse lysosomes (none evident in (A)). In (B) a macrophage-like cell is shown with enlarged lysosomes (L), mainly in clusters, marginal filipodia (F), and an example of an unidentified amorphous granule (U). $(\times 14780)$.

within the joints in inflammatory arthritis are frequently, and perhaps chronically, subjected to high concentrations of hydrogen ions. In the present study we found that $\mathrm{pH}$ changes similar to those observed in rheumatoid synovial fluids can produce alterations in the behaviour of synovial intimal cells, including enhancement of GAG production and activation of the lysosomal system. The wide variations in $\mathrm{pH}$ alone had no appreciable effects on growth rates, and the hyperplasia commonly seen in rheumatoid synovia is therefore likely to be due to other stimuli.

Initially stimulation of GAG production by low $\mathrm{pH}$ was indicated by a gross and consistent increase in the amount of precipitate formed in low $\mathrm{pH}$ media in the 'mucin clot' test ${ }^{18}$ which is used as a qualitative index of GAG production by synovial cells. Quantitative measurement by the isotopic procedure demonstrated that the differences were due largely to the comparitively high molecular weight of GAG released from the cells in conditions of low $\mathrm{pH}$. Studies in this and other laboratories indicate that at least $90 \%$ of the GAG secreted by human synovial cells in culture hyaluronic acid (HA). ${ }^{16}{ }^{19} \mathrm{~A}$ similar response to low $\mathrm{pH}$ in rat embryonic fibroblasts ${ }^{20}$ supports the view that increase in HA production might be a typical response of GAG-producing cells to lower $\mathrm{pH}$. Our findings indicate that the low viscosity of synovial fluid in rheumatoid patients $^{11}$ is unlikely to be a consequence of the decreased $\mathrm{pH}$ often noted in the joints of these patients. On the other hand the molecular weight of GAG secreted by synovial cells at $\mathrm{pH}$ values near to normal was considerably lower than expected from our experience with these cells cultured in standard bicarbonate-buffered medium, though variability is common in these conditions. At this stage it is not 


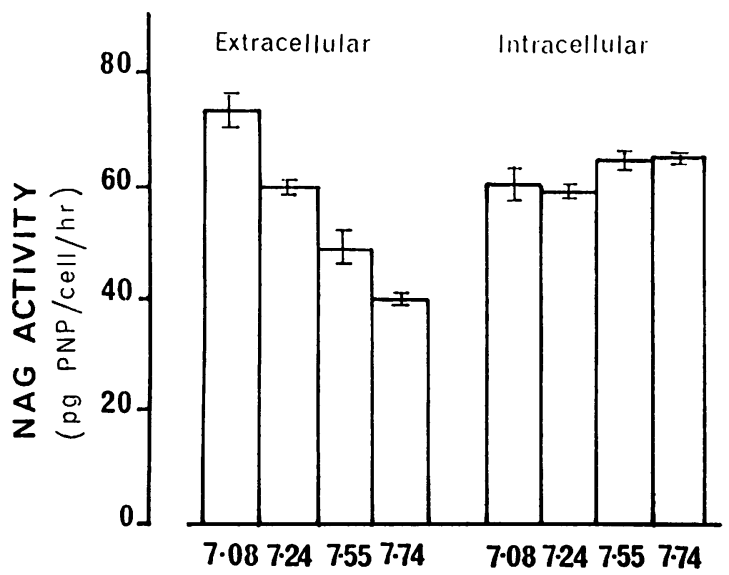

Fig. 6 Influence of $\mathrm{pH}$ on intra- and extracellular activity of NAG. The cells were cultured for $48 \mathrm{~h}$ in EBM $+10 \%$ HS. NAG was determined as in 'Materials and methods'. Vertical bars are means from 4 replicate cultures $( \pm S E M)$.

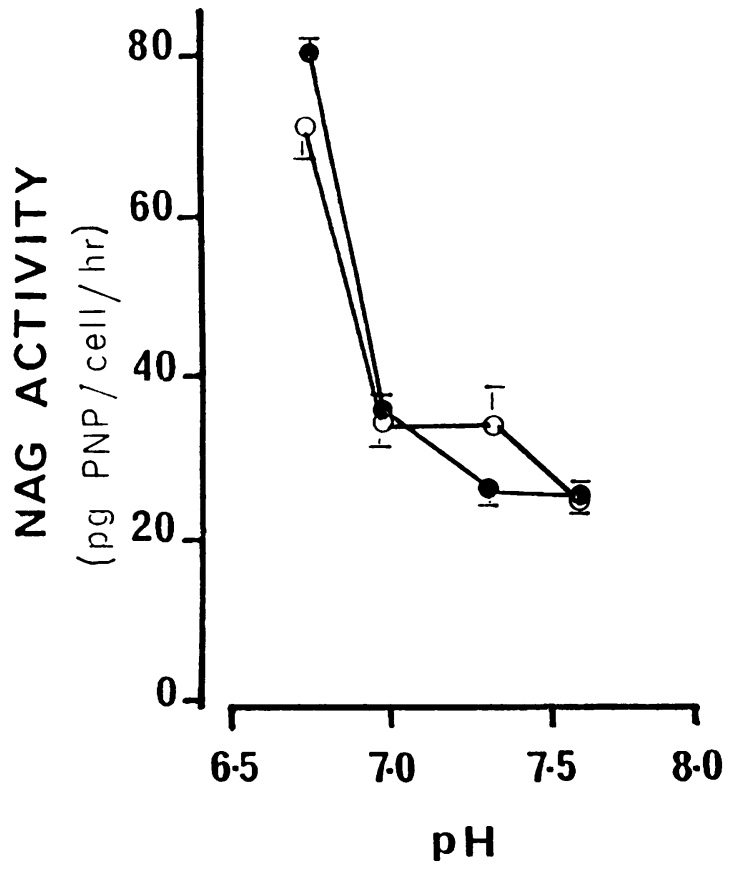

Fig. 7 NAG activity in culture supernatants before (O) and after (O) $48 \mathrm{~h}$ dialysis at $4^{\circ} \mathrm{C}$ against $0.01 \mathrm{M}$ tris- $\mathrm{HCl}$, pH 7.0, with $0.15 \mathrm{M} \mathrm{NaCl}$ and $0.001 \mathrm{M}$ $\mathrm{CaCl}_{2}$. The dialysis equalised each supernatant to $\mathrm{pH} 7 \cdot 0$. Points are means of determinations from 4 replicate cultures $( \pm S E M)$.
Table 2 Effect of variation $p H$ in culture media on intraand extracellular activities of NAG from synovial cells cultured in serum-free medium*

\begin{tabular}{|c|c|c|c|c|}
\hline \multirow{2}{*}{$\begin{array}{l}\text { Initial } \\
p H\end{array}$} & \multirow{2}{*}{$\begin{array}{l}\text { Final } \\
p H\end{array}$} & \multicolumn{3}{|c|}{$N A G^{\dagger}$} \\
\hline & & $\begin{array}{l}\text { Intracellular } \\
(\text { mean } \pm S E M) \\
(n=4)\end{array}$ & $\begin{array}{l}\text { Extracellular } \\
(\text { mean } \pm S E M) \\
(n=4)\end{array}$ & Total \\
\hline $6 \cdot 50$ & $6 \cdot 61$ & $107 \cdot 4 \pm 8 \cdot 5$ & $76 \cdot 7 \pm 2 \cdot 7$ & $184 \cdot 1$ \\
\hline 6.95 & $7 \cdot 19$ & $135 \cdot 6 \pm 5 \cdot 2$ & $61 \cdot 2 \pm 2 \cdot 1$ & $196 \cdot 8$ \\
\hline $7 \cdot 37$ & $7 \cdot 62$ & $125.5 \pm 0.7$ & $43.3 \pm 0.7$ & $168 \cdot 8$ \\
\hline $7 \cdot 55$ & $7 \cdot 71$ & $133 \cdot 8 \pm 4 \cdot 7$ & $32 \cdot 4 \pm 1 \cdot 5$ & $165 \cdot 2$ \\
\hline $7 \cdot 74$ & $7 \cdot 82$ & $146 \cdot 2 \pm 2 \cdot 3$ & $26 \cdot 6 \pm 1 \cdot 2$ & $172 \cdot 8$ \\
\hline
\end{tabular}

* The medium contained BSA at $4 \mathrm{mg} / \mathrm{ml}$ in EBM. Duration of the incubation was $48 \mathrm{~h}$.

+ Activity of $\mathrm{N}$-acetyl-B-glucosaminidase (NAG) was assayed by determining $p$-nitrophenol released from the substrate as described in 'Materials and methods'.

possible to specify whether the smaller molecules produced at higher $\mathrm{pH}$ reflect impaired polymerisation during synthesis or extracellular breakdown. Degradation due to hyaluronidase is an unsatisfactory explanation, since release of hyaluronidase from synovial cells cannot be induced, even by substances which produce gross stimulation of the lysosomal system. ${ }^{15}$ Another possibilty is the absorption of energy from beta emission in the particular conditions of $\mathrm{pH}$ and buffer composition gave rise to enhanced generation of free radicals, which can cause degradation of $\mathrm{HA} .{ }^{21}$ From a practical viewpoint the enhanced secretion at low $\mathrm{pH}$ suggests a means for optimising the producton of high-grade $\mathrm{HA}$ for other experimental purposes.

The swollen organelles seen by phase contrast in synovial cells grown in low $\mathrm{pH}$ media included structures clearly identifiable by electron microscopy as lysosomes, and also bodies of about the same size as the lysosomes, but lacking recognisable features. These bodies bore a resemblance to the so-called type 1 inclusions noted by Lie et al. ${ }^{22}$ in human skin fibroblasts, which, however, were produced in media of unusually high $\mathrm{pH}$. In both cases the accumulation of these obscure bodies in the cytoplasm might signify incipient degenerative changes, though in the case of the synovial cells such changes would not be consistent with the sustained growth rates. The apparent swelling of lysosomes in response to low pH occurred without increase in intracellular activity of NAG. However, there was a pronounced increase in extracellular NAG, and the fraction released therefore appears to be newly synthesised enzyme secreted without storage. The mechanism might involve passive loss in association with increased pinocytosis or a controlled exocytosis. This is an area for further investigation. 
We have previously found that release of NAG by human synovial cells can be promoted by adenosine ${ }^{23}$ and also by $E$ or $F$ type prostaglandins ${ }^{24}$ which are putative mediators of inflammation. More recently a similar reaction was found to occur in response to a soluble factor produced by human peripheral blood monocyte-macrophages (Clarris and Hamilton, unpublished results).

The total lysosomal response in the inflamed joint might therefore be due to many factors, perhaps amplified by interactions. Though the lysosomal complex contains proteolytic enzymes such as cathepsin $\mathrm{B}$, which is potentially capable of acting in the breakdown of cartilage matrix, ${ }^{4}{ }^{25}$ the activity of these enzymes is in general likely to be blocked after release owing to unfavourable $\mathrm{pH}$, except perhaps in the most extreme cases of $\mathrm{pH}$ depression. On the other hand, as suggested by Dingle,${ }^{26}$ much lower $\mathrm{pH}$ values are possible in microenvironments between closely opposed tissues at cartilage-pannus junctions. Lowered $\mathrm{pH}$ in these locally protected sites might induce the release and enhance the activity of lysosomal enzymes from intimal cells while partially suppressing the activity of neutral proteases such as collagenase and plasminogen activator. An analogous model for this hypothetical situation has been described by Vaes, ${ }^{27}$ in which degradation of matrix by osteoclasts correlates more closely with lysosomal hydrolases released into protective resorption zones than with enzymes favoured by neutral $\mathrm{pH}$.

This work was supported by a grant from the National Health and Medical Research Council of Australia. The authors thank Dr K. Granath, Pharmacia AB, Uppsala, for permission to use calibration data for determination of the molecular weight of hyaluronic acid.

\section{References}

1 Cummings N A, Nordby G L. Measurement of synovial fluid $\mathrm{pH}$ in normal and arthritis knees. Arthritis Rheum 1966; 9: 47-56.

2 Treuhaft P S, McCarty D J. Synovial fluid pH, lactate, oxygen and carbon dioxide partial pressure in various joint tissues. Arthritis Rheum 1971; 14: 475-84.

3 Farr M, Kendall M J, Bold A M, Hawkins C F. Significance of pH in synovial fluid. Ann Rheum Dis 1981; 40: 621.

4 Eeckout Y, Vaes G. Further studies on the activation of procollagenase, the latent precursor of bone collagenase. Effects of lysosomal cathepsin B, plasmin and kallikrein. Biochem J 1977; 166: 21-31.

5 Muirden K D. Lysosomal enzymes in synovial membrane in rheumatoid arthritis. Ann Rheum Dis 1972; 31: 265-71.

6 Wegelius $\mathrm{O}$, Klockars M, Vainio U. Acid phosphatase activity in rheumatoid synovium. Acta Med Scand 1968; 183: 549-51.

7 Smith C, Hamerman D. Acid phosphatase in human synovial fluid. Arthritis Rheum 1962; 5: 411-4.

8 Beckman G, Beckman L, Lempery R. Acid phosphatase activity in the synovial fluid of patients with rheumatoid arthritis and other disorders. Acta Rheumatol Scand 1971; 17: 47-56.

9 Jacox R F, Feldmahn A. Variations of B-glucuronidase concentration in abnormal human synovial fluid.J Clin Invest 1955; 34: 263-67.

10 Caygill J C, Pitkeathly D A. A study of $\beta$-acetylglucosaminidase and acid phosphatase in pathological joint fluids. Ann Rheum Dis 1966; 25: 137-44.

11 Castor C W, Prince R K, Hazelton M J. Hyaluronic acid in human synovial effusions; a sensitive indicator of altered connective tissue cell function during inflammation. Arthritis Rheum 1966; 9: 783-94.

12 Fraser J R E, McCall J F. Culture of synovial cells in vitro. Ann Rheum Dis 1965; 24: 351-9.

13 Clarris B J, Fraser J R E. Relationship between chromosomal changes and alterations in the behaviour of a strain of human synovial cells during its life history in vitro. Ann Rheum Dis 1968; 27: 597-603.

14 Ceccarini C. Effect of $\mathrm{pH}$ on plating efficiency, serum requirement and incorporation of radioactive precursors into human cells. In Vitro 1975; 11: 78-86.

15 LeMarshall J, Fraser J R E, Muirden K D. Lysosomal activation by neutral saccharides in cell cultures of synovium. Ann Rheum Dis 1977; 36: 130-8.

16 Castor C W, Bignall M C, Hossler P A, Roberts D J. Connective tissue activation XXI. Regulation of glycosaminoglycan metabolism by lymphocyte (CTAP-I) and platelet (CTAP-III) growth factors. In Vitro 1981; 17: 777-85.

17 Clarris B J, Fraser J R E. The effects of homologous and heterologous whole serum upon multiplication of recentlyisolated human synovial cells in culture. Aust J Exp Biol Med Sci 1967; 45: 549-60.

18 Grossfeld H, Meyer K, Godman G. Differentiation of fibroblasts in tissue culture as determined by mucopolysaccharide production. Proc Soc Exp Biol Med 1955; 8: 31-5.

19 Baxter E, Fraser J R E, Harris G S. Fractionation and recovery of secretions of synovial cells synthesized in culture with radioactive precursors. Ann Rheum Dis 1973; 32: 35-40.

20 Von Kittlich P-D, Neupert G. Experimentelle Beeinflussung der Synthese Saurer Mucopolysaccharide (Glykosaminoglykane) in Fibroblastenkulturen. IV Einfluss des pH-Wertes auf Zellproliferation und MPS-muster. Ex Pathol (Jena) 1972; 7: 117-24.

21 McCord J M. Free radicals and inflammation. Protection of synovial fluid by superoxide dismutase. Science 1974; 185: 529-31.

22 Lie S O, Schofield B H, Taylor H A, Dory S B. Structure and function of the lysosomes of human fibroblasts in culture. Dependence on medium pH. Pediatr Res 1973; 7: 13-19.

23 Fraser J R E, Clarris B J, Baxter E. Patterns of induced variation in the morphology, hyaluronic acid secretion, and lysosomal enzyme activity of cultured human synovial cells. Ann Rheum Dis 1979; 38: 287-94.

24 Clarris B J, Malcolm L P. Effect of prostoglandins $E_{1}, E_{2}$ and $F_{2} \alpha$ on $\mathrm{N}$-acetyl- $\beta$-glucosaminidase activities of human synovial cells in culture. Ann Rheum Dis 1983; 42: 187-91.

25 Burleigh M C, Barrett A J, Lazarus G S. Cathepsin B1. Biochem J 1974; 137: 387-98.

26 Dingle J T. The secretions of enzymes into the pericellular environment. Philos Trans $R$ Soc Lond (Biol) 1975; 271: 315-24.

27 Vaes G. Collagenase, lysosomes and osteoclastic bone resorption. In: Woolley D E, Evanson J M, eds. Collagenase in normal and pathological connective tissues. Wiley and Sons, 1980: 185-207. 